\title{
Histo-Architectural Changes in the Selected Tissues of Litopenaeus vannamei (Boone, 1931) Juveniles Reared in Inland Ground Saline Water (IGSW) fed with Graded Levels of Potassium $\left(\mathrm{K}^{+}\right)$and Magnesium $\left(\mathrm{Mg}^{2+}\right)$ through Feed
}

\author{
Iffat Jahan $^{1 *}$, A.K. Reddy ${ }^{1}$, P.P. Srivastava ${ }^{1}$, V. Harikrishna ${ }^{2}$, \\ Arun S. Sudhagar ${ }^{2}$ and Shashank Singh ${ }^{1}$ \\ ${ }^{1}$ ICAR- Central Institute of Fisheries Education, Mumbai- 400 061, India \\ ${ }^{2}$ ICAR- Central Institute of Fisheries Education- Rohtak Centre, Lahli, Rohtak-124 411, India \\ *Corresponding author
}

A B S T R A C T

\begin{tabular}{|c|c|}
\hline & us vannamei, is an ideal animal for studying the histological alterations caused \\
\hline $\begin{array}{l}\text { Ke y w o r d s } \\
\text { Hepatopancreas, } \\
\text { Gills, Intestine. }\end{array}$ & $\begin{array}{l}\text { IGSW and } 100 \% \mathrm{~K}^{+} \mathrm{Mg}^{2+} \text { fortified IGSW at par with sea water at constant salinity of } 10 \\
\text { ppt. Experiment was conducted for a period of } 60 \text { days. Three diets were formulated using } \\
\text { commercial shrimp feed with varied } \mathrm{K}^{+} \text {and } \mathrm{Mg}^{2+} \text { levels }\left(\mathrm{K}^{+}=5 \mathrm{~g} / \mathrm{kg}, \mathrm{Mg}^{2+}=150 \mathrm{mg} / \mathrm{kg} \text {; }\right. \\
\left.\mathrm{K}^{+}=10 \mathrm{~g} / \mathrm{kg}, \mathrm{Mg}^{2+}=300 \mathrm{mg} / \mathrm{kg} ; \mathrm{K}^{+}=15 \mathrm{gg} / \mathrm{kg}, \mathrm{Mg}^{2+}=450 \mathrm{mg} / \mathrm{kg}\right) \text { and the same }\end{array}$ \\
\hline Article Info & $\begin{array}{l}\text { commercial feed as control diet. Histological alterations were observed such as loss of R- } \\
\text { cells, B-cells and tubular structural damages of hepatopancreas in shrimps reared in raw }\end{array}$ \\
\hline $\begin{array}{l}\text { Accepted: } \\
15 \text { September } 2017 \\
\text { Available Online: } \\
10 \text { November } 2017\end{array}$ & $\begin{array}{l}\text { IGSW. The potassium through feed helped in the maintenance of cellular structure of gills. } \\
\text { In the first, second and third abdominal segments of the gut, increase in the height of } \\
\text { epithelial cells was observed in shrimps grown in raw IGSW. On the intervention of } \\
\text { potassium in the water, the histological architecture best recovered in treatments. }\end{array}$ \\
\hline & $\begin{array}{l}\text { However, the study indicated that histological structures are shown superior in the fortified } \\
\text { water with fortified feed. }\end{array}$ \\
\hline
\end{tabular}

\section{Introduction}

Inland ground saline water aquaculture is one of the new emerging areas of research and has been developing world over. In India, there are about 8.62 million ha of salt-affected lands and 1.93 million hectare kilometers area with ground saline water (Lakra et al., 2014; Harikrishna et al., 2015), prevalent in North Western States, mainly in the arid and semiarid regions of Rajasthan, Punjab, Haryana, and Gujarat and to a lesser extent in Delhi, Uttar Pradesh, Bihar, Madhya Pradesh, Karnataka, Maharashtra, and Tamil Nadu. The quality of inland ground saline water
(IGSW) is quite different than natural seawater, mainly in ionic composition. Potassium concentration is very low as compared to natural sea water at different salinities. Similarly, high levels of calcium and variable levels of magnesium in inland ground saline water (IGSW) are causing problem to undertake aquaculture ventures (Lakra et al., 2014).

The IGSW at ICAR-CIFE Rohtak Centre, Haryana, India has extremely high $\mathrm{Na}^{+} / \mathrm{K}^{+}$ ratios (300:1) and potassium supplementation 
in the water decreases the $\mathrm{Na}^{+} / \mathrm{K}^{+}$ratio, thus made it more suitable for shrimp farming (Antony, 2013., Antony, et al., 2015). High $\mathrm{Na}^{+} / \mathrm{K}^{+}$ratio of the culture medium affects $\mathrm{Na}^{+} \mathrm{K}^{+}$-ATPase activity (Pequeux, 1995; Pan et al., 2006), thereby, affecting the growth, survival, and energy partition (Zhu et al., 2004). The lack of an adequate supply of potassium in the water has been shown negative impact on growth and survival of $L$. vannamei (McGraw and Scarpa, 2004). It is apparent that $\mathrm{K}^{+}$levels in the diet affect the physiology of shrimp. On the other hand lack of adequate $\mathrm{Mg}^{2+}$ or $\mathrm{K}^{+}$affected $\mathrm{Na}^{+} \mathrm{K}^{+}$ATPase activity in crustaceans (Furriel et al., 2000; Pequeux, 1995) resulting in osmotic stress. In order to grow shrimp in the IGSW, potassium salts are often added in water to maintain desirable potassium level (Liu, 2001; Li et al., 2002).

The culture of $L$. vannamei in low salinity was demonstrated by Davis et al., (2002). Farmers in the West Alabama have been successful in raising L. vannamei in IGSW by raising the $\mathrm{K}^{+}$and $\mathrm{Mg}^{2+}$ levels of their pond waters to correct ionic ratio imbalances (McNevin et al., 2004). In India, the culture of L. vennamei was successfully demonstrated and commercialized in $\mathrm{K}^{+}$and $\mathrm{Mg}^{2+}$ fortified IGSW by Lakra et al., (2014).

In general, two separate strategies have been utilized by researchers to improve survival and growth of L. vannamei reared in low saline water. These strategies include feed modification, offered to shrimp, usually with supplements that might theoretically improve osmo-regulatory capacity (Roy et al., 2010). Second strategy is the culture of marine shrimp in pond system with ionic supplementation in water (McNevin et al., 2004). It is reported that the use of fertilizers for the ionic fortification in inland saline aquaculture water could be costly. Hence dietary supplementation of ions such as $\mathrm{K}^{+}$ and $\mathrm{Mg}^{2+}$ in the feed could be a cost effective strategy for inland shrimp culture operation (Roy and Davis, 2010).

The exposure of aquatic organisms to even very low levels of chemicals, salinity or mineral concentration in their environment may result in various histological, biochemical and physiological changes in vital organs and/ or tissues (Hinton et al., 1973; Gupta and Singh, 1982). Similarly, histological alterations have been characterized in various crustacean species of Macrobrachium and Palaemonetespugio exposed to various chemicals such as copper, pentachlorophenol, dithiocarbamates, mercury, cadmium and zinc (Doughtie and Rao, 1983; Rao and Doughtie, 1984; Vijayaraman, 1993). In the shrimp culture histological analysis of the hepatopancreas has been used as a practical means for assessing the nutritional status (Gimenez et al., 2004). Thus far there have been no studies to evaluate the histological changes of gills, intestine and hepatopancreas on L. vannamei related to different dietary potassium $\left(\mathrm{K}^{+}\right)$and magnesium $\left(\mathrm{Mg}^{2+}\right)$ levels reared in IGSW. Hence, the present study was commenced to find the histological changes of L. vannamei juveniles fed with different dietary potassium $\left(\mathrm{K}^{+}\right)$and magnesium $\left(\mathrm{Mg}^{2+}\right)$ levels reared in IGSW.

\section{Materials and Methods}

\section{Preparation and proximate composition of experimental diets}

Three gelatin coated experimental diets were formulated by using commercial shrimp feed with varied $\mathrm{K}^{+}$and $\mathrm{Mg}^{2+}$ levels $\left(\mathrm{K}^{+}=5 \mathrm{~g} / \mathrm{kg}\right.$, $\mathrm{Mg}^{2+}=150 \mathrm{mg} / \mathrm{kg}-\mathrm{F} 1$ feed, $\mathrm{K}^{+}=10 \mathrm{~g} / \mathrm{kg}$, $\mathrm{Mg}^{2+}=300 \mathrm{mg} / \mathrm{kg}-\mathrm{F} 2$ feed, $\mathrm{K}^{+}=15 \mathrm{~g} / \mathrm{kg}$, $\mathrm{Mg}^{2+}=450 \mathrm{mg} / \mathrm{kg}-\mathrm{F} 3$ ) and commercial shrimp feed served as basal diet (F4). The feed fortification was done with commercially 
available fertilizer Muriate of potash $(60 \%$ $\mathrm{K}^{+}$, and Magnesium chloride $\left(27 \% \mathrm{Mg}^{2+}\right)$. Bloom type (BG) gelatin crystals were used at the rate of $4 \mathrm{~g} / 100 \mathrm{~g}$ feed as coating agent (Roy et al., 2006). The proximate composition of experimental diets (\% dry matter basis) was done by following standard methods (AOAC, 1995). Protein content of experimental diets ranged between $33.84 \pm 0.01$ to $35.34 \pm 0.01$.

\section{Experimental design and acclimatization}

The experiments have been carried out for a period of 60 days at ICAR-CIFE Rohtak Center, Lahli-Baniyani Farm, Haryana, India. Completely Randomized Design (CRD) was followed in the experiment, consisted of three treatments with three different dietary potassium and magnesium levels and a control with three replicates of each treatment. Inland ground saline water (IGSW) with commercial shrimp feed was used as control group (C), $\mathrm{K}^{+}-\mathrm{Mg}^{2+}$ fortified water (FW) with commercial shrimp feed was used as treatment T1, IGSW with three different fortified feeds (FF) at $\mathrm{K}^{+}=5 \mathrm{~g} / \mathrm{kg}, \mathrm{Mg}^{2+}=150$ $\mathrm{mg} / \mathrm{kg}$ feed $(\mathrm{F} 1$ feed $), \mathrm{K}^{+}=10 \mathrm{~g} / \mathrm{kg}, \mathrm{Mg}^{2+}=$ $300 \mathrm{mg} / \mathrm{kg}$ feed ( $\mathrm{F} 2$ feed) and $\mathrm{K}^{+}=15 \mathrm{~g} / \mathrm{kg}$, $\mathrm{Mg}^{2+}=450 \mathrm{mg} / \mathrm{kg}$ feed (F3 feed) were used as treatment $\mathrm{T} 2, \mathrm{~T} 3$ and $\mathrm{T} 4$ respectively, and $\mathrm{FW}$ with $\mathrm{FF}$ at $\mathrm{K}^{+}=5 \mathrm{~g} / \mathrm{kg}, \mathrm{Mg}^{2+}=150 \mathrm{mg} / \mathrm{kg}$ feed, $\mathrm{K}^{+}=10 \mathrm{~g} / \mathrm{kg}, \mathrm{Mg}^{2+}=300 \mathrm{mg} / \mathrm{kg}$ feed and $\mathrm{K}^{+}=15 \mathrm{~g} / \mathrm{kg}, \mathrm{Mg}^{2+}=450 \mathrm{mg} / \mathrm{kg}$ feed were used as treatment T5, T6 and $\mathrm{T} 7$ respectively.

The experimental shrimp L. vannamei were procured from Geekay Hatcheries, Nellore, Andhra Pradesh, India. The shrimp were acclimatized and nursed in 500L capacity FRP tanks at constant salinity of $10 \mathrm{ppt}$ for a period of 6 days with aeration and ad libitum feeding. After acclimatization, experiment was performed in 24 uniform size polyethylene containers of each $100 \mathrm{~L}$ capacity. Out of which 12 tubs were filled with raw IGSW water and rest of the tubs was filled with $100 \% \mathrm{~K}^{+} \mathrm{Mg}^{2+}$ fortified water. Each tub was stocked with 10 nos. of $L$. vannamei juveniles with mean body weight (g) $3.19 \pm 0.18-3.76 \pm 0.006$.

\section{Histological Study}

In order to study the histological changes occurred, as a result of dietary modification in raw inland ground saline water, and potassium and magnesium fortified water, the shrimps from each tank were collected upon termination of the 60 days experiment.

Samples of hepatopancreas, gills and intestine were fixed in Davidsons fixative (95\% ethanol, acetic acid, formalin, de-ionized water) and passed through the process of dehydration, block making, sectioning, staining and microscopic observations. Slides were examined under a Phase contrast microscope (Model: Zeiss, Scope A1, Germany) and photographs were taken at $10 \mathrm{X}$.

\section{Results and Discussion}

\section{Histoarchitecture of the hepatopancreas}

The hepatopancreas of treatment T6 (Fig.1T6) L. vannamei exhibited well-organized glandular tubular structure normally observed in the shrimp. Shrimp hepatopancreas are composed of many hepatopancreas tubules. Four kinds of cells dominate the hepatopancreas tubules, namely $\mathrm{E}$ ("embryonalzellen" or embryonic) cells, R ("restzellen") cells, F ("fibrillenzellen" or fibrous) cells, and B ("blasenzellen") cells. In treatment T2 (Fig.1-T2) the number of hepatopancreas B cells significantly increased while in treatment T3 (Fig.1-T3) the B- cells increased more in number. In treatment $\mathrm{T} 4$ (Fig.1=-4), the size of B cells become almost normal. The cells exhibited normal 
architecture with differential cells at each concentration. The interstitial sinuses between tubules were normal.

The structure of hepatopancreas was not normal in control due to the deficiency of potassium and histological changes were more noticed in treatment T2 (Fig.1-T2) groups. In treatment T6 (Fig.1-T6) groups the cellular architecture improved compared to control as the number of R- cells was much higher. Abnormal interstitial sinus and lumen were observed in treatment T7 (Fig.1-T7). However, treatment T1 (Fig.1-T1) showed normal cellular structure.

\section{Histoarchitecture of the gills}

The cellular structure of gills of $L$. vannamei in treatment T6 (Fig.2-T6) exhibited well organized structure showing primary gill filament are branched from central axis. The secondary gill lamella appeared as finger type structures attached to primary gill lamella which embedded to supportive rays. The gills structure of L. vannamei in T2 (Fig.2-T2) treatment groups exhibited vaculation and fusion of gill lamella. In T3 (Fig.2-T3) treatment the fusion of gill lamella and more space created in lamella cellular space. In case of treatment T4 (Fig.2-T4) the pillar cells at interconnecting space or lacunae were interspersed between the pillar cells increased and showing deformities.

In treatment T5 (Fig.2-T5) group cellular structures were not improved but in case of treatment T6 (Fig.2-T6) group the cellular structure of primary gill lamella and branchial arch gill rays were organized, it means fortification of potassium and magnesium support the normal gill structure. The treatment T7 (Fig.2-T7) group exhibited well organized cellular structure of the gill of $L$. vannamei. It was as good as T1 (Fig.2-T1) treatment group.
The potassium through feed helped in the maintenance of cellular structure of gills. All the cells of gill lamella are showing normal structure, however the structure of gill is better in water fortified with fortified feed in comparison to raw IGSW with fortified feed.

\section{Histoarchitecture of the Intestine of $L$. vannamei}

Dietary interventions have been shown to have multiple effects on the gastrointestinal (GI) tract in shrimp models, including physiological, morphological and environmental influences.

In the control (Fig.3-C) group the epithelial cells and cellular structure of villi are columnar in shape, showing normal intestinal crypts, villi and laminar propria. In treatment T1 (Fig.3-T1) the mean height of epithelial cells in first abdominal segment of shrimp was significantly greater than those of control shrimp.

The increase in epithelial cells height was observed in the first, second and third abdominal segments of the gut in the shrimp reared in raw inland ground saline waters (Figs.3-T2, T3 and T4). The cross sections of shrimp mid-gut recovered in treatment T5 (Fig. 3-T5) on the intervention of potassium in the water, the histological architecture was best recovered in treatment T6 (Fig.3-T6). The shrimp mid-gut showed mild recovery in treatment T7 (Fig.3-T7)

This research is the first attempt to describe about the histological changes of three different tissues such as hepatopancreas, gills and intestine of $L$. vannamei reared in fortified water (FW) and raw IGSW fed with or without fortified feed, however literature surveyed showed that there were no records on histological changes of shrimp fed with potassium and magnesium fortified diet. 
Fig.1 Typical organization of the hepatopancreas of control (C) and all treatments i.e., T1, T2, T3, T4, T5, T6 and T7 at 10X magnification of juvenile L. vannamei. B= B-cells (Blasenzellen cells) with their large apical secretory vacuoles, IS= Interstitial sinuses, LU= Lumen; ALU= Abnormal Lumen; E= Embryonic Cells, R= R-cells (Restzellen cells), $\mathrm{F}=\mathrm{F}-\mathrm{cells}$ (Fibrillenzellen cells)

Fig.2 Typical organization of the gills of control (C) and all treatments i.e., T1, T2, T3, T4, T5, T6 and T7 has done at 10X magnification of juvenile L. vannamei. Afp- Afferent vessel, EfpEfferent vessels, Cut- Cuticular walls, Sep- septum, Pil- Epithelial pillar cell processes, NecCell necrosis, PL- Primary lamellae, SL- Secondary lamella
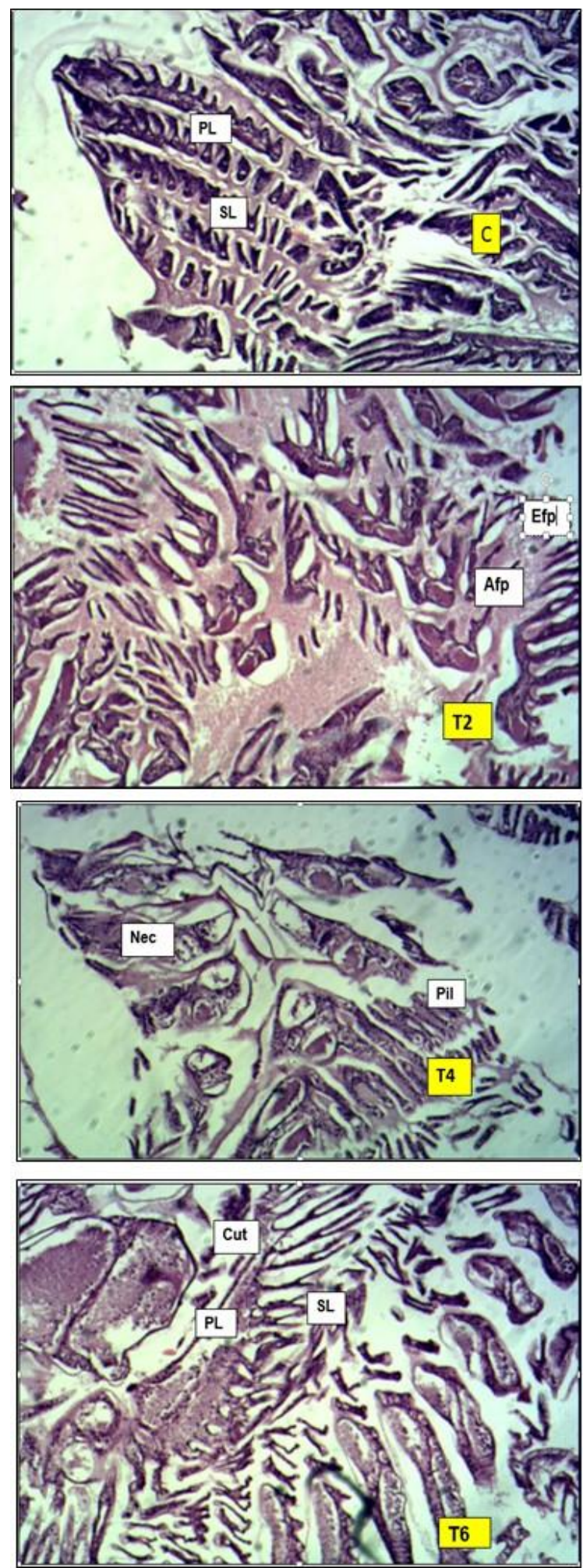
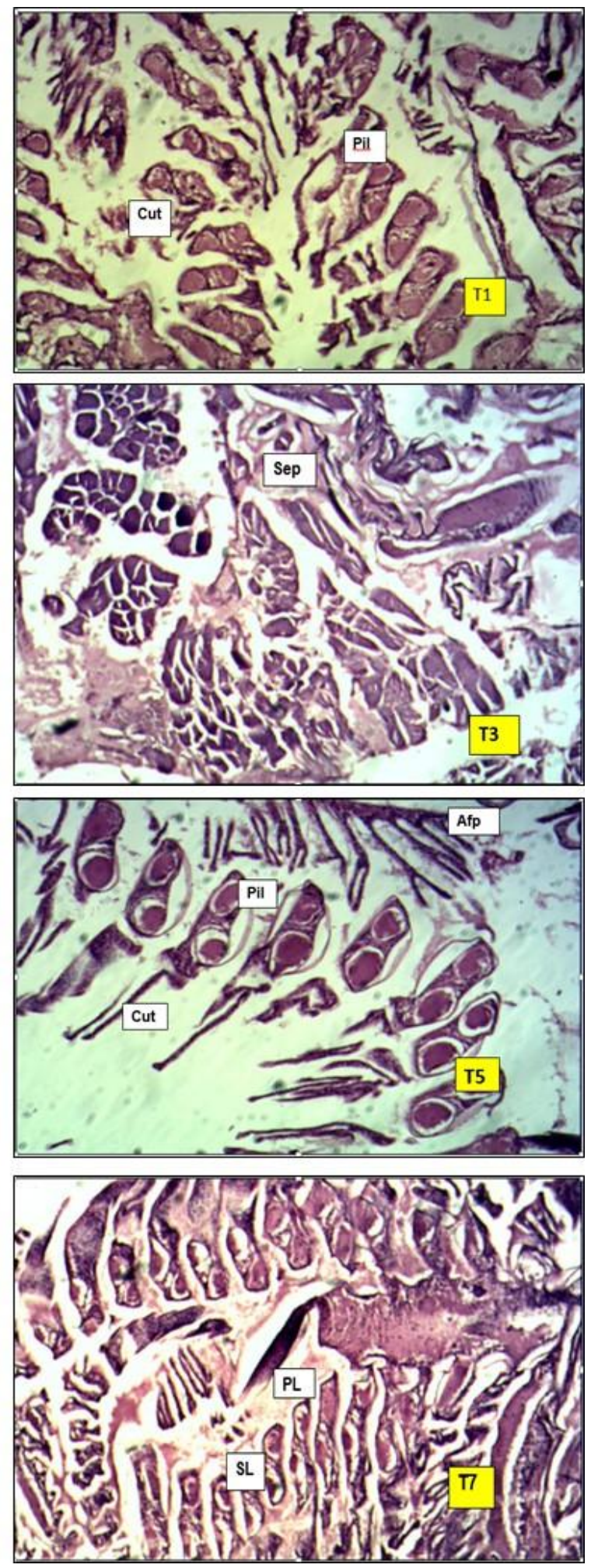
Fig.3 Typical organization of the intestine of control (C) and all treatments i.e., T1, T2, T3, T4, T5, T6 and T7 has done at 10X magnification of juvenile L. vannamei.
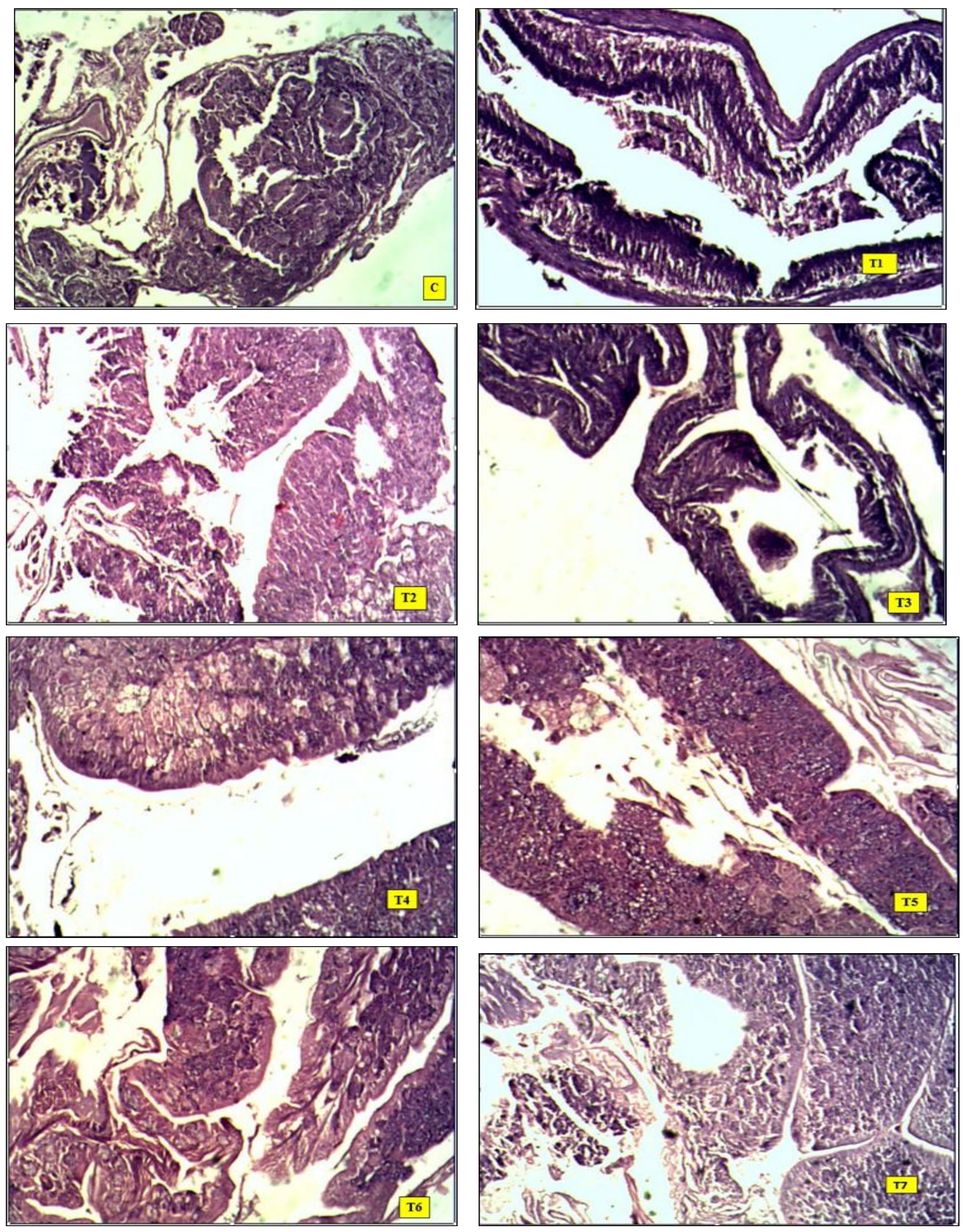
Therefore, some records were found on the $L$. vannamei exposed to cadmium and zinc. $\mathrm{Wu}$ et al., (2009) demonstrated that acute exposure to high concentrations of $\mathrm{Cd}$ and $\mathrm{Zn}$. The exposure of aquatic organisms to even very low levels of chemicals, salinity or mineral concentration in their environment may result in various physiological, biochemical and histological changes in vital organs and/ or tissues (Hinton et al., 1973; Gupta and Singh, 1982). Similarly, histological alterations have been found in crustaceans such as Palaemonetespugio and various species of Macrobrachium exposed to various chemicals such as copper, dithiocarbamates, mercury, cadmium, pentachlorophenol, and zinc (Vijayaraman, 1993; Doughtie and Rao, 1983; Rao and Doughtie, 1984).

Hepatopancreas plays several important roles in metabolic processes of crustaceans (Caceci et al., 1988). It acts as a digestive organ possesses (Caceci et al., 1988; Dall and Moriarty, 1983). It is essentially composed of branched tubules and of different types of epithelial cells (E-cells, R-cells, F-cells and B-cells) lining the tubules. Therefore, it is likely that exposure to different salinity and potassium fortification, would be reflected in alterations in the structure of the tubules and epithelial cells. Some studies related to heavy metals such as cadmium and Zinc $(\mathrm{Cd}$ and $\mathrm{Zn})$ showed, alterations within the hepatopancreas of $L$. vannamei caused retardation of growth (Wu and Chen, 2005), similar effects have been also found in the present study because of deficiency of $\mathrm{K}^{+}$$\mathrm{Mg}^{2+}$ minerals either in feed or water. Hepatopancreas and liver are very sensitive organs to water pollutants and different types or composition of feed (Bautista et al., 1994). Similarly in the present study it was found that even different concentrations of $\mathrm{K}^{+}$$\mathrm{Mg}^{2+}$ minerals, reflected alterations in structure of epithelial cells and tubules of hepatopancreas.
Hepatopancreas is essentially composed of branched tubules with different cells (E-cells, R-cells, F-cells and B-cells) lining the tubules. The B-cells are the main site for the synthesis of digestive enzymes (Caceci et al., 1988). The nutrients mobilization in the tubules of hepatopancreas, supply more energy for the osmoregulation of shrimp in low and high salinities, therefore shrimps comes under environmental stress ( $\mathrm{Li}$ et al., 2007). The R-cells is the main site for the nutrient reserve in the hepatopancreas (Caceci et al., 1988). Therefore, if number of R-cells reduced in low salinity, it might be due to the high energy demand for osmoregulation which utilizes reserved nutrients from R-cells (Li et al., 2007). This suggested that salinity with $\mathrm{K}^{+}$fortification has impact on the physiology in turn on the histological alterations in shrimp. The finding of our study, similar result, and the cellular architecture improved compare to control as the number of R-cells was much higher in treatment T6 groups and, in treatment T2 and $\mathrm{T} 3$ the number of hepatopancreatic B-cells significantly increased compared to T6 treatment but it might be due to deficiency of $\mathrm{K}^{+}-\mathrm{Mg}^{2+}$ minerals either in feed or in water because lack of adequate $\mathrm{Mg}^{2+}$ or $\mathrm{K}^{+}$can affect $\mathrm{Na}^{+} \mathrm{K}^{+}$-ATPase activity in crustaceans (Furriel et al., 2000; Pequeux, 1995) resulting in osmotic stress. The histological changes in the mid-gut gland was observed growth depression of the crustacean (Vogt et al., 1985; Catacutan et al., 1989 and Storch et al., 1984) when fed a diet deficient in either folic acid, riboflavin and ascorbic acid.

In particular, Correia et al., (2002), Yang et al., (2007) and Manisseri and Menon (1995) reported about the copper induced histological damage of hepatopancreas in the amphipod Gammarus locusta, the crab Eriocheirsinensis and of the shrimp Metapenaeusdobsoni respectively, in addition $\mathrm{Zn}, \mathrm{Cd}$ and $\mathrm{Pb}$ causes several alterations in the structure of 
hepatopancreatic cells in the isopod Porcellioscaber (Kohler et al., 1996). Therefore, it is likely that exposure to different salinity and potassium fortification was reflected in alterations in the structure of the tubules and epithelial cells.

Gills of aquatic organisms are vital organs help in regulation of osmotic and ionic balance and transportation of respiratory gases. Toxic substances may damage gill tissues, thereby disrupting the osmoregulatory function and reducing the oxygen consumption of aquatic organisms (Ghate and Mulherkar, 1979). The morphology of gill filaments is similar to other species of penaeid shrimps (Woodward et al., 1988). When gills exposed to low salinity exhibited several alterations that include detachment and lifting of the epithelial linings from the surfaces of the gill filament (primary lamellae) and respiratory (secondary lamellae) lamellae. This leads to extensive haemorrhage from the gills. Due to prolonged exposure, the neighbouring secondary lamellae fused together and the entire gills appeared as solid mass of undifferentiated cells in $15 \%$ o salinity exposed with inland ground saline water (Pathak, 2013). Subsequently, the ladder-like arrangement of the pillar cells-blood capillaries of the gills also collapsed, causing asphyxiation and the death of the shrimp ( $L$. vannamei). Pathak (2013) also reported that rearing of shrimp even in low levels of salinity (5\%) and higher $\mathrm{K}^{+}(75 \%$ and $100 \%)$ can result in histological changes in hepatopancreas and gills, whereas, in case of medium with higher salinity of $10 \%$ and $15 \%$ with $75 \%$ and $100 \% \mathrm{~K}^{+}$fortification yielded better results. Therefore, it is suggested that the aquatic environment with $10 \%$ and $15 \%$ with $75 \%$ and $100 \% \mathrm{~K}^{+}$is best for the rearing of the shrimp in inland ground saline water systems and there is major histological alterations observed in low levels of salinity and even at higher $\mathrm{K}^{+}$fortification. The results of the present study is corroborating with the results of Pathak (2013). In decapods histological alterations of gill tissues have been reported due to higher concentration of heavy metals such as $\mathrm{Cd}, \mathrm{Zn}, \mathrm{Cu}$ and $\mathrm{Pb}$ in Penaeusduorarum (Couch,1977), Macrobrachiumrosenbergi( $\mathrm{Li}$ et al., 2007), Procambarusclarkii (Torreblance et al., 1989) and E. sinensis (Yang et al., 2007). These metals caused alterations in functional and structural changes of gills, resulting hypoxia (Li et al., 2007). In the histological study of current experiment, changes in gill filaments were observed after exposure to different concentration of potassium and magnesium in feed either in fortified water or in raw IGSW.

Histological study of intestine is important because they correlate different morphological structure with physiological functions such as digestion of food, nutrient assimilation and adaptation to changes of salinity (Yamamoto and Hiraro, 1978; Cataldi et al., 1998) also useful in nutritional stress condition and assessing disease status (Williams and Nickol, 1989). The alimentary canal of a decapod crustacean arises from an ectodermal stomodeum, an endodermal mesenteron, and an ectodermal proctodeum (Vonk 1960; Shiino 1968; Johnson 1980). Result of Eckmann (1985) shows that the histological alterations of the intestinal epithelium in the foregut and mid-gut of whitefish (Coregonussp) larvae when fed on excess ration of zooplankton. Intestinal micro villi provide a vast absorptive surface area, the increase in micro villi density and/or length can increase nutrient absorptive ability (Sang and Fotedar, 2010). Fontagne, et al., (1998) observed in common carp, that due to deficiency of dietary phospholipid, resulting an increase in height of mucosal epithelium, a reduced total liver volume, mean hepatocyte volume and an accumulation of fat droplets in the enterocytes of the anterior intestine. A reduction of the enterocyte height has been 
used as an indicator of starvation in larvae (Segner et al., 1993; McFadzen et al., 1994; Theilacker and Watanabe, 1989). Regarding the good growth of carp larvae fed Artemia or phosphatidylcholine-enriched diets (Geurden et al., 1998), result showed the decrease of enterocyte height was not due to underfeeding conditions, and it might be because of active lipid absorption with diffuse appearance. Salma et al., (2011) reported about the histological changes in intestine of beluga (Husohuso) by exposure of two different bacterial strains. Similarly in the current experiment, alterations were observed in the height of epithelial cells. Those shrimps which were reared in fortified water fed with fortified feed, shown best recovery in the structure of epithelial cells of the intestine especially in T6 group, it is due to providing $\mathrm{K}^{+}-\mathrm{Mg}^{2+}$ minerals both in feed and ambient water, therefore reared shrimps are not in osmotic stress, resulting better growth and survival.

The results of the present study indicated that the fortification of commercial feed with potassium and magnesium is highly beneficial to maintain the regular structure of hepatopancreas, gills and intestine of shrimps, resulting into the normal growth particularly when reared in raw inland ground saline water.

\section{Acknowledgments}

The authors are thankful to Dr. Gopal Krishna, Director, ICAR-Central Institute of Fisheries Education (CIFE), Mumbai, for providing facilities for carrying out this work. They also record their sincere thanks to Dr. W.S Lakra, ICAR-Officer on Special Duty (Blue Revolution) and former Director, ICAR-CIFE for the valuable co-operation and guidance for this research work. The first author also thanks the Indian Council of Agricultural Research (ICAR), New Delhi for providing financial assistance during course work in CIFE.

\section{References}

Antony, J. (2013). Effects of salinity and $\mathrm{Na}^{+} / \mathrm{K}^{+}$ratio on physiological and production parameters of black tiger prawn (Penaeusmonodon Fabricius, $1798)$ reared in inland saline water. (Master Thesis). Central Institute of Fisheries Education, Mumbai, Maharashtra, India.

Antony, J., Vungurala, H., Saharan, N., Reddy, A. K., Chadha, N. K., Lakra, W. S., and Roy, L. A. (2015). Effects of salinity and $\mathrm{Na}^{+} / \mathrm{K}^{+}$ratio on osmoregulation and growth performance of black tiger prawn, Penaeusmonodon Fabricius, 1798, juveniles reared in inland saline water. Journal of the World Aquaculture Society, 46(2), 171-182.https://dx.doi.org/ 10.1111/jwas.12179-v46-2-182

AOAC.(1995). Official Methods of Analysis. $13^{\text {th }}$ Edition. Association of Official Analytical Chemist, Washington, D.C. $1038 \mathrm{pp}$

Bautista, M. N., Lavilla- Pitogo, C. R., Subosa, P.F., and Begino, E. T. (1994). Aflatoxin B1 contamination of shrimp feeds and its effect on growth and hepatopancreas of pre- adult Penaeusmonodon. Journal of the Science of Food and Agriculture, 65(1), 5-11. https://dx.doi. org/10.1002/jsfa.2740650 103- v65-1-11

Caceci, T., Neck, K. F., Lewis, D. D. H., and Sis, R. F. (1988). Ultrastructure of the hepatopancreas of the pacific white shrimp, Penaeusvannamei (Crustacea: Decapoda). Journal of the Marine Biological Association of the United Kingdom, 68(2), 323-337.https://dx.doi. org/10.1017/S002531540005222X-v68-2337.

Catacutan, M. R., and De la Cruz, M. (1989). Growth and mid-gut cells profile of Penaeusmonodon juveniles fed watersoluble-vitamin deficient diets. Aqua 
culture, 81(2), 137-144. https://dx.doi. org/10.1016/0044-8486(89)90239-1-v81$2-144$

Cataldi, E., Di Marco, P., Mandich, A., and Cataudella, S. (1998). Serum parameters of Adriatic sturgeon Acipensernac carii (Pisces: Acipenseriformes): effects of temperature and stress. Comparative Biochemistry and Physiology Part A: Molecular and Integrative Physiology, 121(4), 351-354. https://dx. doi.org/10.1016/S1095-6433(98)10134-4v121-4-354

Correia, A. D., Lima, G., Costa, M. H., and Livingstone, D. R. (2002). Studies on biomarkers of copper exposure and toxicity in the marine amphipod Gammarus locusta (Crustacea): I. Induction of metallothionein and lipid peroxidation. Biomarkers, 7(5), 422437.http://dx.doi.org/10.1080/135475002 760413516-v7-5-437

Couch, J. A. (1977). Ultrastructural study of lesions in gills of a marine shrimp exposed to cadmium1. Journal of invertebrate pathology, 29(3), 267288.https://dx.doi.org/ 10.1016/S00222011(77)80032-3-v29-3-288

Dall, W., and Moriarty, D. J. W. (1983).Functional aspects of nutrition and digestion. The biology of Crustacea, 5, 215-261.

Davis, D. A., Saoud, I. P., McGraw, W. J., and Rouse, D. B. (2002). Considerations for Litopenaeus vannamei reared in inland low salinity waters. VI Symposium International the Nutrition Acicula, 3-6 pp.

Doughtie, D. G., and Rao, K. R. (1983). Ultrastructural and histological study of degenerative changes in the antennal glands, hepatopancreas, and midgut of grass shrimp exposed to two dithiocarbamate biocides. Journal of invertebrate pathology, 41(3), 281300.https://dx.doi.org/ 10.1016/00222011(83)90245-8-v41-3-300

Eckmann, R. (1985). Histopathological alterations in the intestine of whitefish
(Coregonus sp.) larvae reared on zooplankton from Lake Constance. Diseases of Aquatic Organisms, 1(1), 1117. https://dx.doi.org/10.017-S103/85/00 01/05.00-v1-1-17

Fernandez Gimenez, A. V., Fenucci, J. L., and Petriella, A. M. (2004).The effect of vitamin $\mathrm{E}$ on growth, survival and hepatopancreas structure of the Argentine red shrimp Pleoticusmuelleri Bate (Crustacea, Penaeidea). Aquaculture research, 35(12), 1172-1178. https://dx. doi.org/1111/j.1365-2109.2004.01142.xv35-12-1178

Fontagne, S., Geurden, I., Escaffre, A. M., and Bergot, P. (1998). Histological changes induced by dietary phospholipids in intestine and liver of common carp (Cyprinus carpio L.) larvae. Aquaculture, 161(1), 213-223.https://dx.doi.org/ 10.1016/S0044-8486(97)00271-8-v161-1223

Furriel, R. P. M., McNamara, J. C., and Leone, F. A. (2000). Characterization of $\left(\mathrm{Na}^{+}\right.$, $\mathrm{K}^{+}$)-ATPase in gill microsomes of the freshwater shrimp Macrobrachium olfersii. Comparative Biochemistry and Physiology Part B: Biochemistry and Molecular Biology, 126(3), 303315.https://dx.doi.org/ 10.1016/S03050491 (00)00184-X-v126-3-315

Geurden, I., Marion, D., Charlon, N., Coutteau, P., and Bergot, P. (1998).Comparison of different soybean phospholipidic fractions as dietary supplements for common carp, Cyprinuscarpio, larvae. Aquaculture, 161(1), 225-235. https://dx.doi.org/10.10 16/S00 44-8486(97)00272-X-v161-1-235

Ghate, H. V., and Mulherkar, L. (1979). Histological changes in the gills of two freshwater prawn species exposed to copper sulphate [India]. Short communication. Indian Journal of Experimental Biology. http://agris.fao. org/agris

Gupta, A., and Singh, C. P. (1982). Histopathological changes in different tissues of $T$. fasciatus under the acute impact of BHC. Toxicology letters, 14(3- 
4), 151-156. https://dx.doi.org/10.1016/ 0378-4274 (82)90044-3-v14-3-4-156

Harikrishna, V; Arun S. Sudhagar and A. K. Reddy. (2015).A Bane Turned to Boon: Litopenaeus vannamei culture using ionic manipulation in inland salt affected areas of Haryana, India. Fishing Chimes. Vol. 35, No.9, 25-27 pp.

Hinton, D. E., Kendall, M. W., and Silver, B. B. (1973). Use of histologic and histochemical assessments in the prognosis of the effects of aquatic pollutants. In Biological methods for the assessment of water quality.

Johnson, P. T. (1980). Histology of the blue crab, Callinectessapidus: a model for the Decapoda. Praeger Publishers,New York, $440 \mathrm{pp}$.

Kohler, H. R., Hiittenrauch, K., Berkus, M., Graff, S., and Alberti, G. (1996).Cellular hepatopancreatic reactions in Porcellioscaber (Isopoda) as biomarkers for the evaluation of heavy metal toxicity in soils. Applied Soil Ecology, 3(1), 115.https://dx.doi.org /10.1016/0929-1393 (95)00073-9-v3-1-15

Lakra,W. S., Reddy, A. K. and Harikrishna, V. 2014. Technology for commercial farming of Pacific white shrimp Litopenaeus vannamei in inland saline soils using ground saline water. Central Institute of Fisheries Education, Mumbai, Maharashtra, India, Technical Bulletin-1, $28 \mathrm{pp}$.

Li, C. Wang., Zhu, F, and Wang, H. (2002).Techniques for Litopenaeus vannamei culture with inland saline ground water. Shandong Fish, 19, 6-8 pp.

Li, N., Zhao, Y., and Yang, J. (2007). Impact of waterborne copper on the structure of gills and hepatopancreas and its impact on the content of metallothionein in juvenile giant freshwater prawn Macrobrachium rosenbergii (Crustacea: Decapoda). Archives of Environmental Contamination and Toxicology, 52(1), 7379.https://dx.doi.org/10.1007/s00244-005 -0214-5-v52-1-79

Liu, J. M. (2001). Experiment on raising the survival of Chinese shrimp Fenneropenaeus chinensis in saline groundwater. Shandong Fisheries, 18(1), 13-14 pp.

Manisseri, M. K., and Menon, N. R. (1995). Copper-induced damage to the hepatopancreas of the penaeid shrimp Metapenaeus dobsoni-an ultrastructural study. Diseases of aquatic organisms, 22(1), 51-57. https://dx.doi.org/10.3354/d ao022051-v22-1-57

McFadzen, I. R. B., Lowe, D. M., and Coombs, S. H. (1994). Histological changes in starved turbot larvae (Scophthalmus maximus) quantified by digital image analysis. Journal of Fish Biology, 44(2), 255-262. https://dx.doi.org/10.1111/j.109 5-8649.1994.tb01203.x-v44-2-262

McGraw, W. J., and Scarpa, J. (2004). Mortality of freshwater-acclimated Litopenaeus vannamei associated with acclimation rate, habituation period, and ionic challenge. Aquaculture, 236(1), 285-296. https://dx.doi.org/10.1016/j.aquaculture. 2 004.01.037-v236-1-296

McNevin, A. A., Boyd, C. E., Silapajarn, O. and Silapajarn, K. $2004 . \quad$ Ionic supplementation of pond waters for inland culture of marine shrimp. Journal of the World Aquaculture Society, 35: 460 - 467. https://dx.doi.org/10.1016/j.aqua culture. 2004.01.037-v35-467

Pan, L. Q., Luan, Z. H., and Jin, C. X. (2006). Effects of $\mathrm{Na}+/ \mathrm{K}+$ and $\mathrm{Mg} 2+/ \mathrm{Ca} 2+$ ratios in saline groundwaters on $\mathrm{Na}+\mathrm{K}+-$ ATPase activity, survival and growth of Marsupenaeus japonicus postlarvae. Aquaculture, 261(4),13961402.https://dx.doi.org/10.1016/j.aquacult ure.2006.09.031-v261-4-1402

Pathak, M. S. 2013. Ionic manipulation of inland saline ground water for growth and survival of Litopenaeus vannamei (Boone, 1931). (Master Thesis). ICARCentral Institute of Fisheries Education, Mumbai, Maharashtra, India

Pequeux, A. 1995.Osmotic regulation in crustaceans. Journal of Crustacean Biology, 15, 1-60. https://dx.doi.org/10. 
2307/1549010-v14-1-4-395

Rao, K. R., and Doughtie, D. G. (1984).Histopathological changes in grass shrimp exposed to chromium, pentachlorophenol and dithiocarba-mates. Marine Environmental Research, 14(1-4), 371-395. https://dx.doi.org/10.1016/01411136 (84)90089-8-v14-1-4-395

Roy, L. (2006). Physiological and nutritional requirements for the culture of the Pacific white shrimp, Litopenaeus vannamei, in low salinity waters. (Ph.D. Thesis).

Roy, L. A., Davis, D. A., Saoud, I. P., Boyd, C. A., Pine, H. J., and Boyd, C. E. (2010). Shrimp culture in inland low salinity waters. Reviews in Aquaculture, 2(4), 191-208. https://dx.doi.org/10.1111/j. 1753- 5131.2010.01036.x-v2-4-208

Roy, L. and Davis, A. 2010. Supplementation of potassium, magnesium, and sodium chloride in practical diets for the pacific white shrimp Litopenaeus vannamei, reared in low salinity waters. Reviews in Aquaculture, 2(4), 46-60. https://dx.doi. org/10.1111/j.1365-2095.2007.00460.xv2-4-60

Salma, W., Zhou, Z., Wang, W., Askarian, F., Kousha, A., Ebrahimi, M. T., and Ring $\varnothing$, E. (2011). Histological and bacteriological changes in intestine of beluga (Husohuso) following ex vivo exposure to bacterial strains. Aquaculture, 314(1), 24-33.https://dx.doi.org/10.1016/ j.aquaculture.2011.01.047-v314-1-33

Sang, H. M., and Fotedar, R. (2010).Effects of mannan oligosaccharide dietary supplementation on performances of the tropical spiny lobsters juvenile (Panulirusornatus, Fabricius 1798). Fish and shellfish immunology, 28(3), 483489. https://dxdoi.org/10.1016/j.fsi.2009. 12.011-v28-3-489

Segner, H., Rösch, R., Verreth, J., and Witt, U. (1993). Larval nutritional physiology: studies with Clariasgariepinus, Coregonuslavaretus and Scophthalmus maximus. Journal of the World Aquaculture Society, 24(2), 121134.https://dxdoi.org/10.1111/j.1749- 7345.1993.tb00001.x-v24-2-134

Shiino, S. M. 1968. Crustacea. In M. Kume and K. Dan (Eds.), Invertebrate Embryology, Chap. 10 (Arthropoda), NOLIT Publishing House, Belgrade.333-388.

Storch, V., Juario, J. V., and Pascual, F. P. (1984). Early effects of nutritional stress on the liver of milkfish, Chanoschanos (Forsskal), and on the hepatopancreas of the tiger prawn, Penaeusmonodon (Fabricius). Aquaculture, 36(3), 229236.https://dx.doi.org/10.1016/0044-8486 (84)90238-2-v36-3-236

Theilacker, G. H., and Watanabe.Y. (1989).Midgut cell height defines nutritional status of laboratory-raised larval northem anchovy, Engraulismordaa'. Fish. Bull., U.S. 457469

Torreblanca, A., Del Ramo, J., and DiazMayans, J. (1989). Gill ATPase activity inProcambarusclarkii as an indicator of heavy metal pollution. Bulletin of environmental contamination and toxicology, 42(6), 829-834.

Vijayaraman, K. (1993). Physiological responses of the freshwater prawn Macrobrachium malcolmsonii_Milne Edwards_to the heavy metals cadmium copper chromium and zinc. (Ph. D. Thesis), Bharathidasan University, India

Vogt, G., Storch, V., Quinitio, E. T., and Pascual, F. P. (1985). Midgut gland as monitor organ for the nutritional value of diets in Penaeusmonodon (Decapoda). Aquaculture, 48(1), 1-12.https://dx.doi. org/10.1016/0044-8486(85)90047-X-v48$1-12$

Vonk, H. J. (1960). Digestion and metabolism. The physiology of Crustacea, 1, 291-316 pp.

Williams, J. A., and Nickol, B. B. (1989).Histological structure of the intestine and pyloric caeca of the green sunfish, Lepomiscyanellus Rafinesque. Journal of Fish Biology, 35(3), 359-372. https://dx.doi.org/10.1111/j.1095-8649. 1989.tb02988.x-v35-3-372

Woodward, D. F., Snyder-Conn, E., Riley, R. 
G., and Garland, T. R. (1988).Drilling fluids and the arctic tundra of Alaska: Assessing contamination of wetlands habitat and the toxicity to aquatic invertebrates and fish. Archives of Environmental Contamination and Toxicology, 17(5), 683697.https://dx.doi.org/10.1007/BF010558 38-v17-5-697

Wu, J. P., and Chen, H. C. (2005).Effects of cadmium and zinc on the growth, food consumption, and nutritional conditions of the white shrimp, Litopenaeus vannamei (Boone). Bulletin of environmental contamination and toxicology, 74(2), 234-241. https://dx.doi.org/10.1007/s00128-004-05 75-X-v74-2-241

Wu, J. P., Chen, H. C., and Huang, D. J. (2009). Histopathological alterations in gills of white shrimp, Litopenaeus vannamei (Boone) after acute exposure to cadmium and zinc. Bulletin of environmental contamination and toxicology, 82(1), 9095. https://dx.doi.org/10.1007/s00128008-9582-7-v82-1-95
Yamamoto, M., and Hirano, T. (1978). Morphological changes in the esophageal epithelium of the eel, Anguilla japonica, during adaptation to seawater. Cell and tissue research, 192(1), 25-38. https://dx.doi.org/10.1007/BF00231020-v -192-1-38

Yang, Z. B., Zhao, Y. L., Li, N., and Yang, J. (2007).Effect of waterborne copper on the microstructures of gill and hepatopancreas in Eriocheirsinensis and its induction of metallothionein synthesis. Archives of environmental contamination and toxicology, 52(2), 222228.https://dx.doi.org/10.1007/s00244-00 6-0133-0-v52-2-222

Zhu, C., Dong, S., Wang, F., and Huang, G. (2004). Effects of $\mathrm{Na}^{+} / \mathrm{K}^{+}$ratio in seawater on growth and energy budget of juvenile Litopenaeus vannamei. Aquaculture, 234(1), 485-496. https://dx.doi.org/10.1016/j.aquaculture.2 003.11.027-v234-1-4

\section{How to cite this article:}

Iffat Jahan, A.K. Reddy, P.P. Srivastava, V. Harikrishna, Arun S. Sudhagar and Shashank Singh. 2017. Histo-Architectural Changes in the Selected Tissues of Litopenaeus vannamei (Boone, 1931) Juveniles Reared in Inland Ground Saline Water (IGSW) fed with Graded Levels of Potassium $\left(\mathrm{K}^{+}\right)$and Magnesium $\left(\mathrm{Mg}^{2+}\right)$ through Feed. Int.J.Curr.Microbiol.App.Sci. 6(11): 1739-1752. doi: https://doi.org/10.20546/ijcmas.2017.611.210 